\title{
Challenges of Disaster Relief Housing: Evaluating Coastal Domestic Typologies in Eastern Sri Lanka
}

\author{
Kira Bre Clingen, Mark Robert Bavoso
}

\begin{abstract}
In the aftermath of the December 2004 tsunami, an unprecedented natural disaster that disproportionately affected the impoverished and conflict-ridden eastern coast of Sri Lanka, the outpouring of disaster relief and support for housing reconstruction was primarily led by international aid organizations for the erection of capitalintensive dwellings to allow for immediate habitation. Three case studies representative of significant housing typologies deployed since the tsunami are investigated: two global prototypes sponsored by foreign aid, and one informal, vernacular construction. We argue that in Sri Lanka the aidhousing-as-commodity paradigm - which in its specificity and immutability disregards the robust tradition of integration between natural and built environments and between individual and community - represents an increasingly and unsustainably risky expenditure of capital resources due to the likelihood of more frequent disasters in coastal zones. We argue for a shift toward spatial frameworks, not static prototypes, which take into account that the longer temporal dimension of rebuilding community and housing after a natural disaster is not necessarily synonymous with expensive, structurally robust building practice.
\end{abstract}

Keywords: coastal vulnerability, community, disaster housing, disaster reduction and relief, foreign aid

The December 26, 2004 Indian Ocean tsunami caused by the SumatraAndaman earthquake was an unprecedented natural disaster that severely affected fourteen countries, including the island nation of Sri Lanka. Across 
Sri Lanka, the death toll surpassed 31,000 , with 516,150 people displaced by the initial tidal wave or ensuing flooding..$^{1,2}$ The financial need for housing reconstruction was estimated at US $\$ 487$ million, which was primarily contributed by international agencies mobilized after the disaster and distributed through owner-driven and donor-driven housing reconstruction programs. ${ }^{3,4}$

\section{BACKGROUND}

\section{Ethnic Conflict, Natural Disaster}

The 2004 tsunami occurred after two decades of civil war between the Sri Lankan military and ethnic Tamil separatists, known as the Liberation Tigers of Tamil Elam (LTTE). ${ }^{5}$ From 1983 to 2009, ethnic strife segregated the island nation, whose population is majority Sinhalese buddhist and approximately one quarter Tamil. ${ }^{6}$ On the East Coast, the population has historically been majority Tamil and prior to the tsunami, uneven power relations between the two groups provoked violence, destruction, and human displacement to these rural areas. ${ }^{7,8}$ During wartime, derelict roadways and infrastructure inhibited supply chains from reaching the coast, public services were inadequately funded and administered, and an estimated one million internally displaced persons (IDPs) were left without homes. ${ }^{9,10}$ The Sri Lankan Civil War created an outsized vulnerability in the country's East, where marginalized civilian populations inhabiting a degraded landscape faced a diminished capacity to provide food, security and shelter. Against the sectarian violence wrought legible across the geography of the nation, the 2004 tsunami landed on the East coast and inordinately affected the impoverished region, destroying 50,450 homes. ${ }^{11}$ The natural disaster immediately superseded the Civil War in determining spatial distribution and usage along the eastern seaboard; it temporarily halted the armed conflict as the LTTE ceded political and spatial control to the Government of Sri Lanka, foreign donors, and non-governmental organizations, before the war ended in May 2009. ${ }^{12}$ However, the geographic isolation of the East Coast has endured, particularly with regards to a lack of infrastructural improvements to extend supply chains from the capital city of Colombo and connect the coastline of the East Coast with the rest of the country.

\section{Initial Government Response and the Coastal Buffer Zone}

In the immediate aftermath of the tsunami, the Sri Lankan government endeavored to construct 57,000 transitional shelter units to house 98,525 IDPs across the nation. ${ }^{13}$ Permanent reconstruction was estimated to be completed within five years by coalitions of donors and government agencies. International and local NGOs would contribute capital, construction materials and skilled labor, while the government would redistribute land. The Sri Lankan government determined two qualifications 
for reconstruction priorities: the creation of a coastal buffer zone, to provide for future disaster resilience, and proof of former housing ownership for disbursement of housing reconstruction funds. Demarcated in January 2005, the buffer zone served as a boundary beyond which housing reconstruction programs were initially required to operate. Affected residents were to be reallocated land outside the buffer zone by the government on which to rebuild, and those without claims to land could apply to receive houses constructed by NGOs outside of the zone on specially allocated plots. ${ }^{14}$

The Sri Lankan Government's buffer zone represented a difficult compromise: the tsunami penetrated in some places along the coast up to $2 \mathrm{~km}$ [1.2 mi.] inland, but local geographic features and settlement patterns ultimately determined which areas were the most affected by the disaster. Unfortunately, upon its introduction, no formal rationale or research for the buffer zone was properly communicated to the general public. ${ }^{15}$ In the absence of government communication as to the role of buffer zones - namely to promote public safety and deter against the loss of life in the face of future coastal disasters - the differences in buffer zone areas seemed politically charged, and appeared to be designed to disenfranchise the livelihoods of East-coast fishermen and their families. ${ }^{16,17}$ Thus the buffer zone on the East coast was initially set at $200 \mathrm{~m}$ [656 ft.] before being revised to $50 \mathrm{~m}[164 \mathrm{ft}.] .{ }^{18}$ The government, largely absent in the region until the tsunami's landfall, supervised the redistribution of land and housing construction beyond the buffer zone, but revisions, ambiguity, and weak enforcement in the buffer zone complicated needs assessments undertaken by international NGOs to distribute housing, and introduced challenges for housing projects whose funding was contingent on the original buffer zone stipulations. ${ }^{19}$ The buffer zone is emblematic of the country's broader failure in enacting a distributed project of enhanced spatial resilience to achieve environmental protection along coastal regions to protect the population from future disasters.

\section{Building Resilient Housing: The Crux of Aid}

The resilience of a socio-ecological system was seminally defined by the ecologist Brian Walker and his colleagues as "the capacity of a system to absorb disturbance and reorganize while undergoing change so as to still retain essentially the same function, structure, identity and feedbacks." 20 In the event of ecological, social, or economic conditions that degrade a system to the point where it cannot recover, a fundamentally new system must be created, or transformed to sustain human settlement. ${ }^{21}$ Because humanitarian aid's most accessible and longitudinal contributions are spatial in nature, housing built after natural disasters disproportionately informs the social, economic, and ecological landscapes of vulnerable zones. At best, aid housing enhances physical and psychological security and helps rebuild localisms and place-based affinity, but when poorly 
planned and executed it can compound inequality and inaccessibility. Across cultures, the house acts as both a social center and form of identity, simultaneously material and symbolic while articulating identity and power. ${ }^{22,23}$ Seminal works, including Clare Cooper Marcus' House as a Mirror of Self (1995), Carole Despres' "The Meaning of Home" (1991) and Amos Rapoport's House Form and Culture (1969), expand on the house as a complex entity defined by cultural, social, demographic and political factors beyond spatial composition. Compared to all other forms of dwelling, the house has a greater impact on the social, economic and political realities of individuals as an indicator of resource ownership. ${ }^{24,25}$ As such, it requires a greater amount of contextual sensitivity than any other physical infrastructure, both in architectural characteristics and construction through distribution. ${ }^{26,27}$

When international donors, consultants and organizations are involved in the construction of the home, the highly personal politics of housing collide with geopolitics. This can create reconstruction patterns which reflect, sustain and reproduce patterns of inequality and exploitation when there is unequal agency between donor and recipients. ${ }^{28}$ Sri Lanka utilized two models in housing reconstruction: a donor-driven and homeowner-driven, or sometimes called cash-based or community-based approach. ${ }^{29,30}$ In the donor-driven approach, housing reconstruction is entirely conceptualized, built and given to recipients by the donor agency, while the owner-driven approach offers funding, technical assistance, troubleshooting, training and supervision by the donor agency, while the recipient maintains full control over the physical housing reconstruction process, including the design of the home. ${ }^{31,32}$ This is an increasingly popular methodology among the donor community, and was used extensively in the reconstruction of Sri Lankan homes after the 2004 tsunami, in which the International Federation of the Red Cross constructed $68 \%$ of their pledged homes through this approach, though the donor-driven approach was used by a majority of donors across the country. ${ }^{33}$

After the tsunami, the lack of a national construction industry with the appropriate number of contractors, equipment, skilled workforce and modern management practices and access to finance was debilitating to reconstruction work. ${ }^{34}$ Community-based development which trains the workforce and stimulates the regional economy, spurring trade, local markets and supply lines, provides manual labor and enhanced livelihoods after the immediate rebuilding process has completed.

If housing aid is an in-kind instead of cash gift, and attempts to introduce or define specific new models or constructions of home, the local agency of vulnerable places may be challenged and eroded by poorly-adapted global construction practices, materials, and conventions. ${ }^{35}$ This erosion is striking in post-tsunami Sri Lanka through a peculiar iconography of aid projects: every aid-sponsored house, school, road, and bridge carries a tile or sign attributing the source of its funding, many bearing prominently the flags 
of Japan, Canada, or the United States (Fig. 1). In isolated communities that did not have roads until post-tsunami construction, these symbols are tangible reminders, over a decade after the event, of the brief intersection of rural Sri Lanka with international aid. In the present day, there is no accountability, either from the organizations to beneficiaries or inhabitants to donors, regarding ownership or occupation of these dwellings.

Furthermore, external reviews found the Government of Sri Lanka relaxed the stipulations and requirements of donor-driven housing as compared to owner-driven housing for international NGOs completing reconstruction work. $^{36}$

Traditionally, beneficiaries are formally accountable to the organizations who provide aid funds, while attempts to create standards of accountability from organizations to beneficiaries beyond roughly quantifiable statistics are overlooked. ${ }^{37}$ The metrics of accountability - numbers of dwellings constructed, miles of road laid, fiscal commitment to projects - mask the nuances that could be provided through qualitative and longitudinal evaluation, particularly in the form of surveyed feedback from users. This is particularly crucial in housing reconstruction projects, in which buildings can become empty within months of their completion. Qualitative data from users is crucial in extending the lifespan of these projects, enacting cultural preferences in spatial layout and organization and generating knowledge of best practices to carry forward.

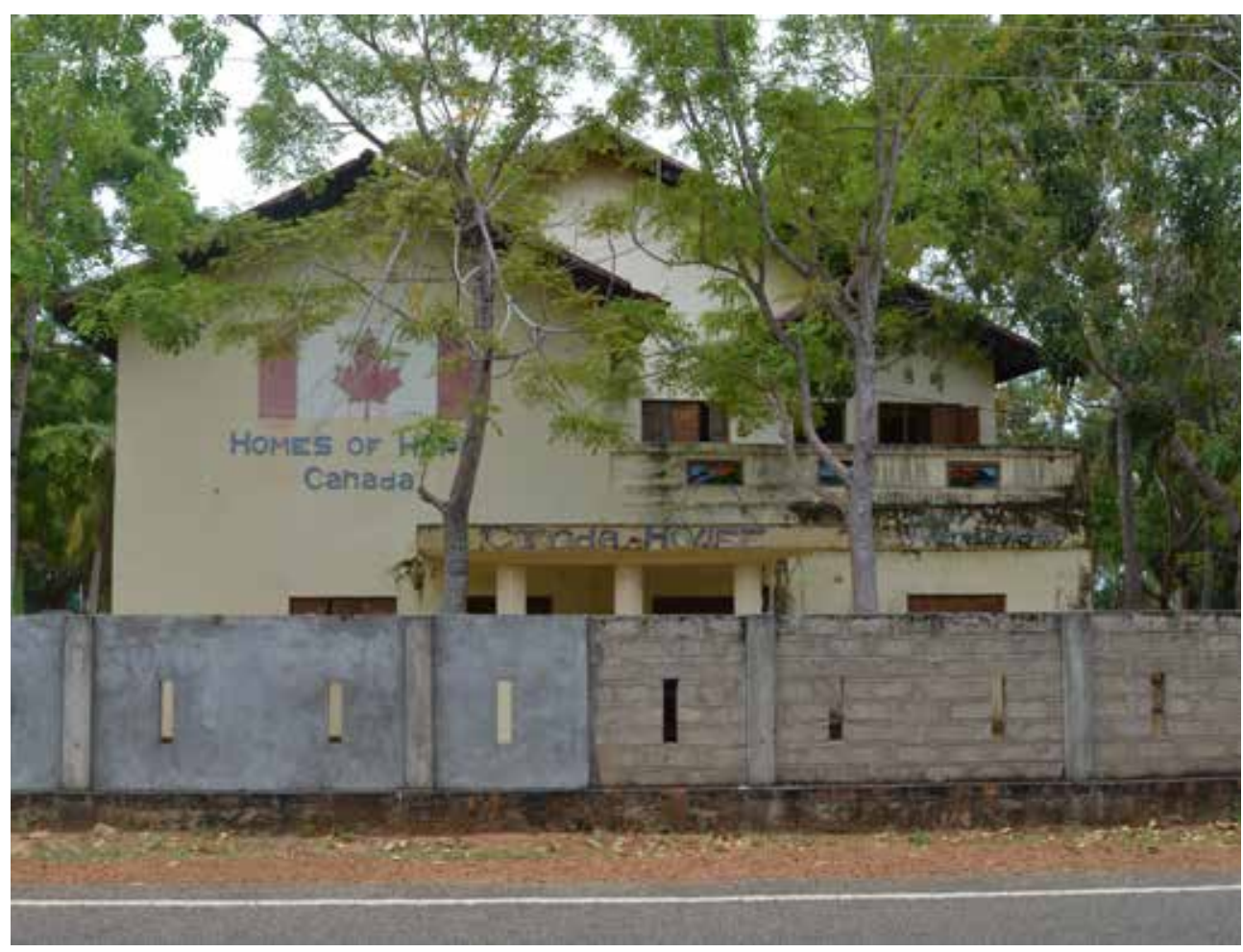

Figure 1. The iconography of Aid, a Canadian-sponsored aid project in Pottuvil bearing the Canadian flag. 
Reconstruction is generally referred to as an approach that attempts to "build back better," even from the limited information available in the immediate aftermath of a crisis. ${ }^{38,39}$ Yet in the aftermath of a tsunami or similar natural disaster, physical devastation may be so traumatic that preexisting vulnerabilities, including social and economic variables that contribute to degraded resilience in the most affected areas, may not be taken into account. Furthermore, studies suggest that an influx of foreign non-governmental organizations reduce vulnerability only as long as their external support remains available to the affected community. After this support is withdrawn, the vulnerability of the community returns to the pre-disaster level, regardless of the physical assets delivered. ${ }^{40}$ Thus, community-based redevelopment allows for adaptation to vulnerabilities beyond those made evident in the period immediately following a natural disaster, and a longitudinal relationship between NGOs, government and local communities and reduces vulnerability. In Sri Lanka, promoting conflict sensitivity and negotiating conflict resolution while planning housing schemes and shared community infrastructure were imperative, but were largely neglected both by international organizations and local officials for the sake of timely reconstruction of physical homes, proof of capital spending for donors. ${ }^{41}$ This disproportionately affected the East Coast, where consultation and engagement by international NGOs was generally more ad hoc and informal than in other areas of the country, leading directly to inhabitants' diminished involvement in the production of housing and inability to address longstanding issues of national inequity. ${ }^{42,43}$ Here, we evaluate the design, materials and process of construction behind two typologies of internationally donor-driven housing projects in Sri Lanka, as well as one vernacular typology. These case studies highlight challenges with the common method of donating abstractly conceived formal prototypes in geographically isolated, disaster-stricken territories.

\section{ENVIRONMENT}

The landscape of Sri Lanka's East coast is largely homogenous. Long swaths of the coast are sandy beaches with steep, three-foot vertical drops in sand that denote the high and low-tide markers. Fishing vessels and mariculture activities are primarily launched from and return to sheltered harbors with sandy bottoms that offer protection from the fierce waves and near-shore coral reefs elsewhere along the eastern coast. Chains of shore-parallel, elongated lagoons form a barrier between the barren sandy beaches and inland rice paddies, and serve as biological hotspots for migrating birds, reptiles and larger mammals, including elephants. ${ }^{44}$ Both the lagoons and surrounding rice paddies occasionally become hyper-saline, particularly along the southeastern coast, disrupting the fishermen and farmers whose livelihoods depend on the freshwater inflows. ${ }^{45}$ The tsunami, which penetrated up to two kilometers inland across the east coast, extended to and salinated rice paddies, many of which lay fallow during the Sri Lankan Civil War. Low-lying scrub vegetation 
dominates the landscape, which lies in the country's dry zone. Shrubs and trees are characterized by thick bark and interlacing canopies for water retention. The vertical landscape is dominated by coconut palms, particularly around the coastal freshwater lagoons. Additional fruit and vegetable species adapted for dry climates, including pineapple, banana, chilies, maize and mung bean can be successfully grown across the east coast, and have traditionally been grown in sustenance gardens adjacent to homes to supplement diets. ${ }^{46}$

\section{CASE STUDIES}

\section{Methodology}

The interpretive fieldwork for this research was undertaken over the course of one month from May to June 2017 in Pottuvil, a town of roughly thirty-five thousand residents on Sri Lanka's eastern coast (Fig. 2). Here we investigated three local projects emblematic of different delivery systems for architectural and urban design principles in disaster relief housing assistance. Pottuvil was severely afflicted by the tsunami and due to its size, it was a site in which NGOs constructed homes in close proximity to

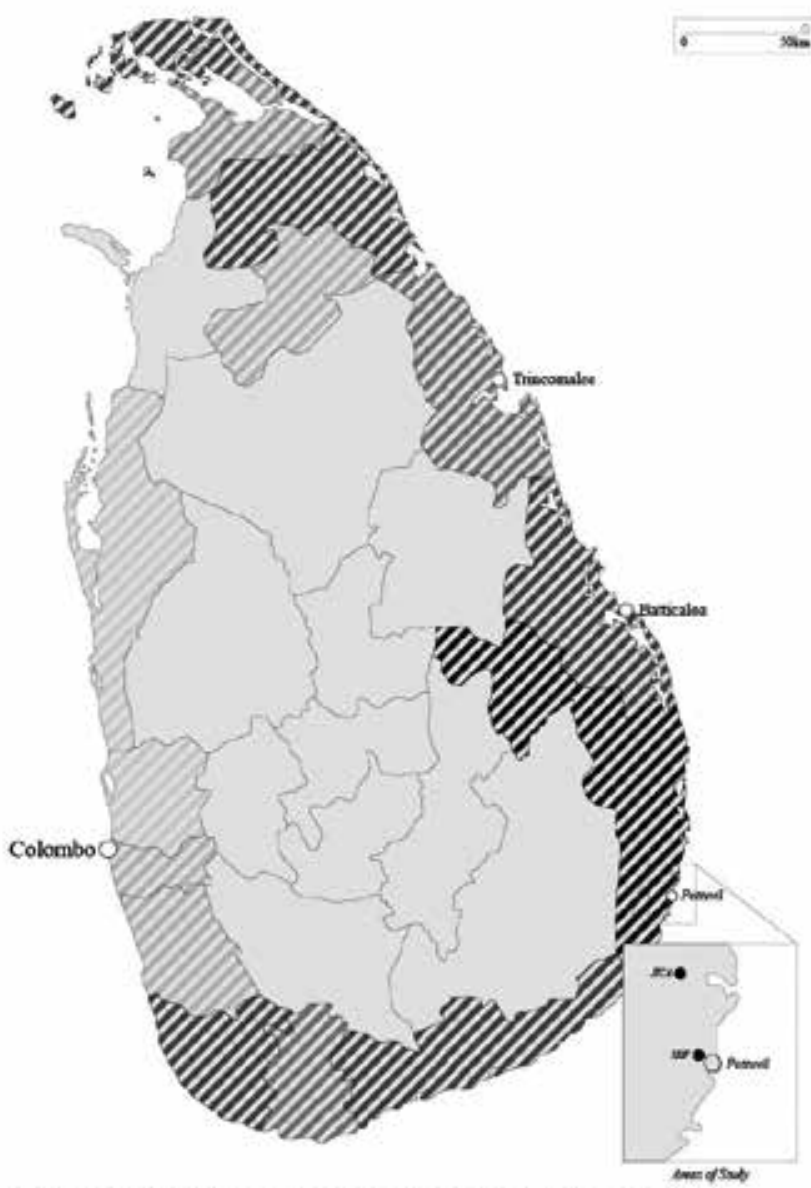

Tsunami Affected Administrative Districts, Sri Lanka, 2004
Figure 2. Districts affected by the December 2004 tsunami and areas of study. Darker shaded areas reflect greater death tolls. 
owner-driven and informal reconstruction efforts using drastically different models, and therefore proved a productive site for comparative study. The research was conducted through informal, semi-structured interviews and three site visits to the developments investigated in this paper, as well as sketching, photography and observations of the three housing typologies. Interviews were conducted based on accessibility to target populations, namely five fishermen within each housing development, each of whom acted as the head of household within their family. The sites for case studies were based on the accessibility of information regarding the schemes and the knowledge of an NGO worker who facilitated translation and had familiarity with the projects. Interviews were used to collect qualitative information on living arrangement, habitation and improvements within each housing scheme. In addition, expert interviews were conducted with NGO leaders by phone, primarily regarding the lessons learned through post-tsunami housing reconstruction and applied to current building projects.

The interviews were conducted with a Tamil translator working with a local NGO, who also facilitated photography of homes and other sites constructed after the tsunami. Thus, the methods used were impacted by the language barrier and necessity to translate questions from English to Tamil. It should be noted that inhabitants of the East coast, and in some cases within single housing schemes, sometimes speak only either Tamil or Sinhalese, leading to situations in which neighbors and community members cannot communicate in a common language. These barriers to communication are heightened by the aforementioned history of strong cultural conflicts between Tamils and Sinhalese which prevented interviews from being undertaken with both populations over the course of individual site visits.

\section{An Architectural Prototype: Monolithic Domes}

The Ecoshell system, developed by the Monolithic Dome Institute, a commercial organization based in Texas, has been deployed by various organizations as aid housing across the world. Monolithic's domed houses reinforced concrete erected using inflatable formwork - are emblematic of a type of formally and technologically distinctive bespoke architectural prototype given as donor-driven in-kind aid. The town of Inspector Eatham, on an elevated plain on the northeastern edge of Pottuvil, is the site of one such relief housing development in Sri Lanka constructed by the Solid House Foundation (SHF), a Dutch NGO. Following the tsunami, some 60 domed ecoshell homes were built by SHF within an existing fabric of agricultural property ownership and small homes and developments (Fig. 3). Construction of the concrete shells begins with the excavation of a circular foundation, into which a reinforced concrete slab or ring beam is poured. When initial curing is complete, inflatable formwork using air pumps is inflated on top, and a cage of rebar is erected around it. Finishing layers 
of concrete are either troweled onto the formwork or propelled as shotcrete. Community meetings were held and a common prototype, $9 \mathrm{~m}$ [29.5 ft.] in diameter, was drawn by SHF to guide the construction process (Fig. 4). ${ }^{47}$

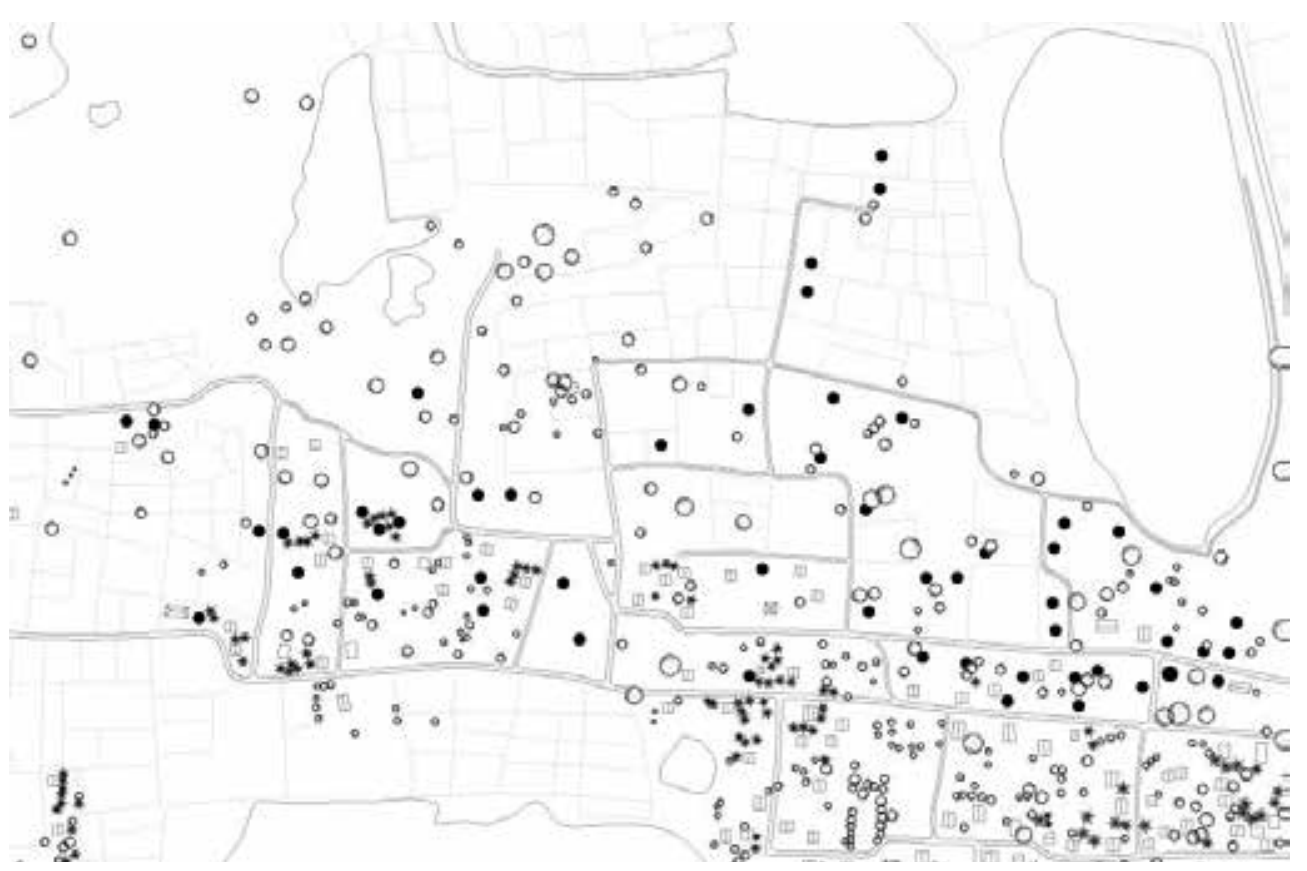

Figure 3. Site plan of Inspector Eatham village, the site of approximately sixty Solid House Foundation dome houses.

Figure 4. Site plan and section of $9 \mathrm{~m}$ [29.5 ft.] diameter prototypical domed dwelling unit planned by SHF for Inspector Eatham.
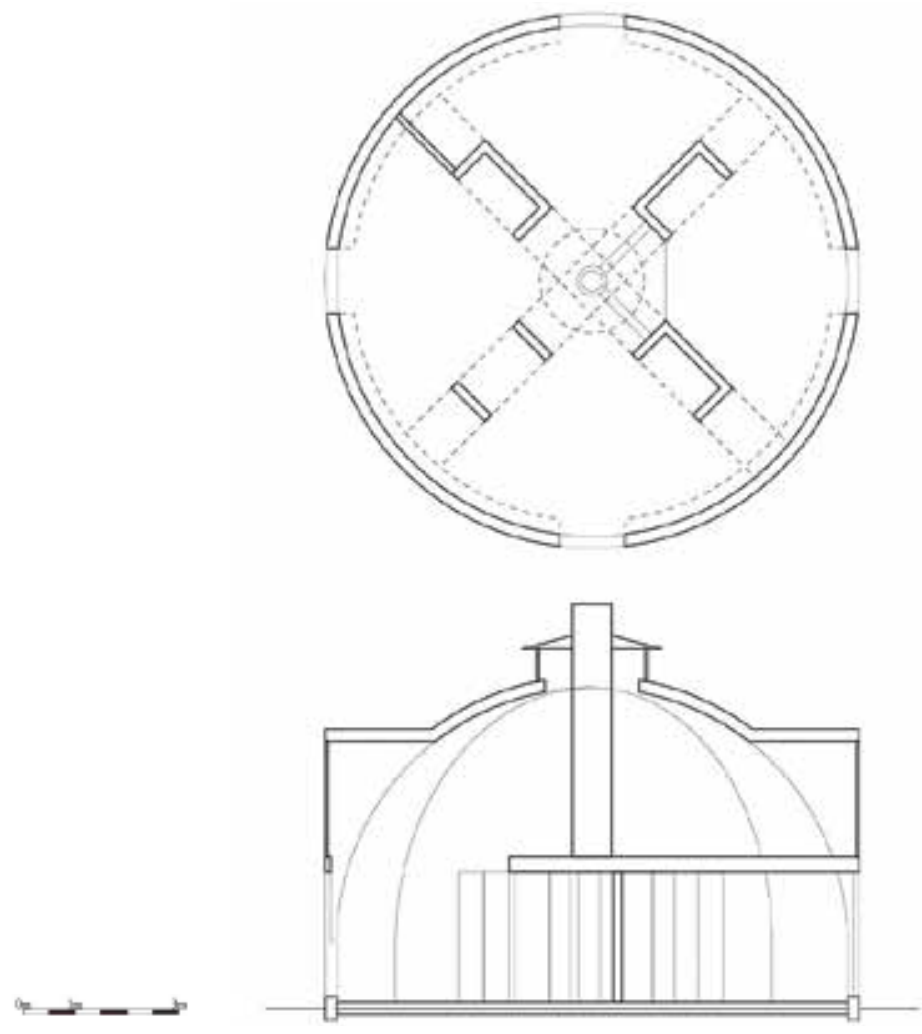


\section{Towards A Flexible Framework: U.N. Habitat \& JICA Spec Homes}

Three and a half km [2.2 mi.] north of Inspector Eatham on a second elevated area, abutting the low-lying rice paddies, is a freestanding housing development of 200 conventional homes sponsored by the Japan International Cooperation Agency (JICA) (Fig. 5). These homes were built from a series of prototypes and specifications from the United Nations Habitat as part of the Indian Housing Project, sponsored by the Government of India to aid in tsunami reconstruction in Sri Lanka. ${ }^{48,49}$ This freely available technical documentation represents a move toward transparency in housing construction, and a shift toward providing the information required to occupants who may choose to modify the existing construction. However, the availability of these schemes in a common language to inhabitants - namely Tamil or Sinhalese - is critical. These prototypes were used as part of an owner-driven reconstruction scheme in the Northern provinces, but deployed as donor-driven in the east, built without the input of the community in an urban grid structure that is foreign to the typical informal layout of villages along the coast. The grid in this project imposes rigid site boundaries that make alternate forms of land use, such as gardens or an informal building to use as a commercial space,

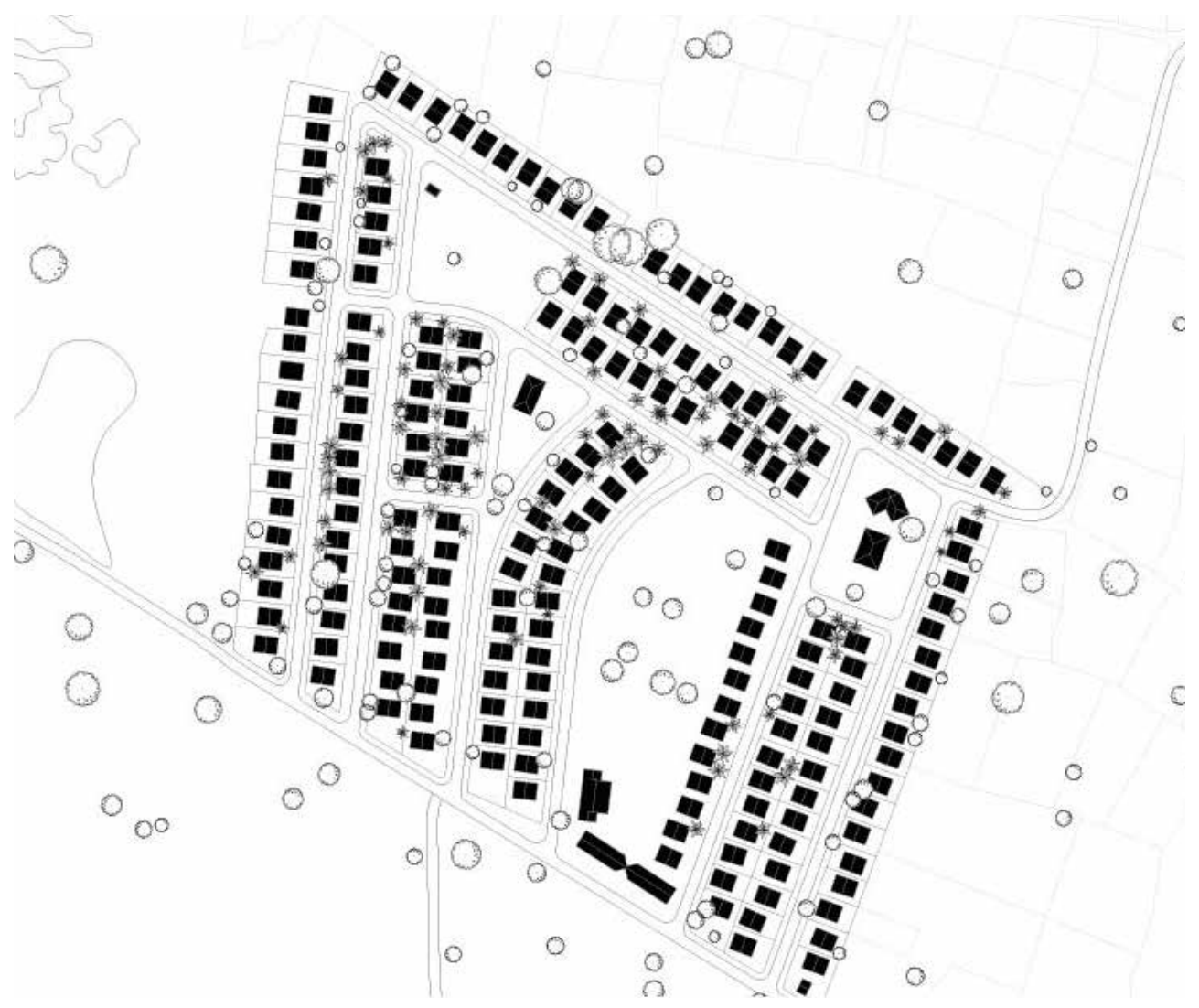

Figure 5. Site plan of the Japan International Cooperation Agency (JICA) development near Pottuvil. The 200 homes are constructed around an artificial grid with rigid perimeters separating each dwelling. 
impossible to accommodate on the plot. The opportunity for the community to engage during the design process to discuss the physical layout of the individual homes and arrangement of the greater scheme might have led to alterations in the construction to better suit the needs of the inhabitants, and extend the useful lives of delivered assets.

\section{Local Vernacular: Cadjan}

Palmyra palm tree leaves - which have a rigid central spine from which long, lancelet leaves extend from either side - woven into mats, termed cadjan in the local vernacular, have been used as a building material across Sri Lanka and greater Asia since antiquity, particularly along the poorer east coast, where geographic isolation and poverty demands the use of easily obtainable, repairable building materials..$^{50}$ Cadjan huts near the coastline in Pottuvil are generally occupied by fishermen, whose boats can be pulled up the beach next to their homes, providing immediate access to the sea and secure storage for vessels. The rectangular, singlestory structures are generally entered only from the side opposite seaward breezes, and the space inside is partitioned by divisions made of additional woven cadjan mats (Fig. 6). Their structural integrity decays over one to three years, after which they must be replaced with additional leaves, which can be sustainably sourced from the area. There is generally no flooring constructed, particularly in fishermen's dwellings built directly onto the sandy beach.

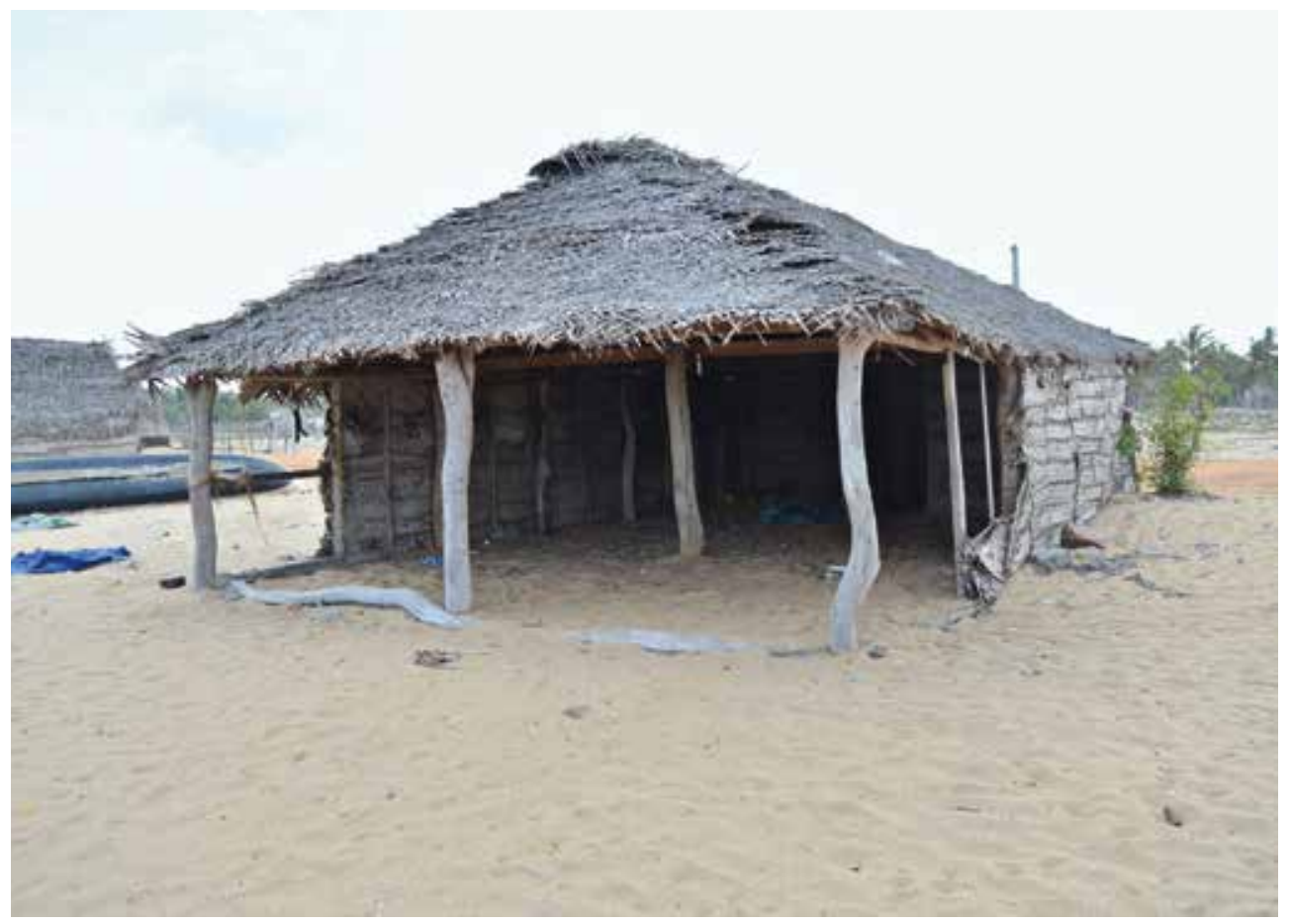

Figure 6. Vernacular cadjan beachfront home along the beach in Pottuvil, with an access road located on the inland side of the home. 
Through interviews and observation, it became clear that the erection of cadjan buildings is generally undertaken by communal groups rather than solely the inhabitants of a house. The roof of a traditional home can be assembled using cadjan by three to four able-bodied men in two days. Generally, the main structure is erected by community members, while secondary considerations not required for shelter, including fencing, are added at the discretion of the family. In times of heavy winds, the buildings must be weighted down unless a framework of timber is secured to a concrete foundation, which has not been common practice along the beach in Pottuvil. Cadjan buildings are especially vulnerable to flooding and require barriers of sandbags, vegetation, or walls to keep water from reaching the structures. These houses offer limited physical security, and rely on the social fabric of the community to ensure privacy, which has historically been tenuous along the east coast.

\section{Evaluation}

At both donor-driven housing sites, we observed high levels of vacancy and widespread disrepair (Figs. 7, 8). In revisiting the specific architectural and urban models deployed in the projects, we posit that their marginal sensitivity to the social and economic needs of the inhabitants of Eastern Sri Lanka's coastline likely contributed to their abandonment. In addition, we argue that they have perpetuated low levels of resilience to the challenges of housing in tropical climates, and to future natural disasters, which are likely to increase in frequency and intensity in the future due to climate change.

Previously in Sri Lanka, the Tsunami Evaluation Coalition found serious problems in housing relief stemming from supply-driven approaches, inappropriate housing designs and an over-reliance on the donor-driven process. ${ }^{51}$ Introduced by international NGOs, the housing typologies we investigated were pre-established generic prototypes that have specific advantages in durability and standardization under idealized circumstances. However, localized site-specific concerns were largely ignored in favor of schemes that position houses as isolated single-family assets, in contrast with the strong history of flexible family living in Sri Lanka. ${ }^{52}$ Furthermore, these aid projects stand rooted in foreign urban models that neglect the realities of programmatic integration familiar to Sri Lankans, specifically the integration of residential and commercial space. In areas surrounding these housing projects residences commonly have a permeable first floor with retail space, while families live in the back of the building. This space is generally used to sell cold water, petrol and pre-packaged foods.

Construction methods and materials were imported and not readily sourced from the eastern coast, where undeveloped infrastructure was degraded during the war, and which remains difficult to reach. The relative isolation of the east coast made the establishment of supply lines more 


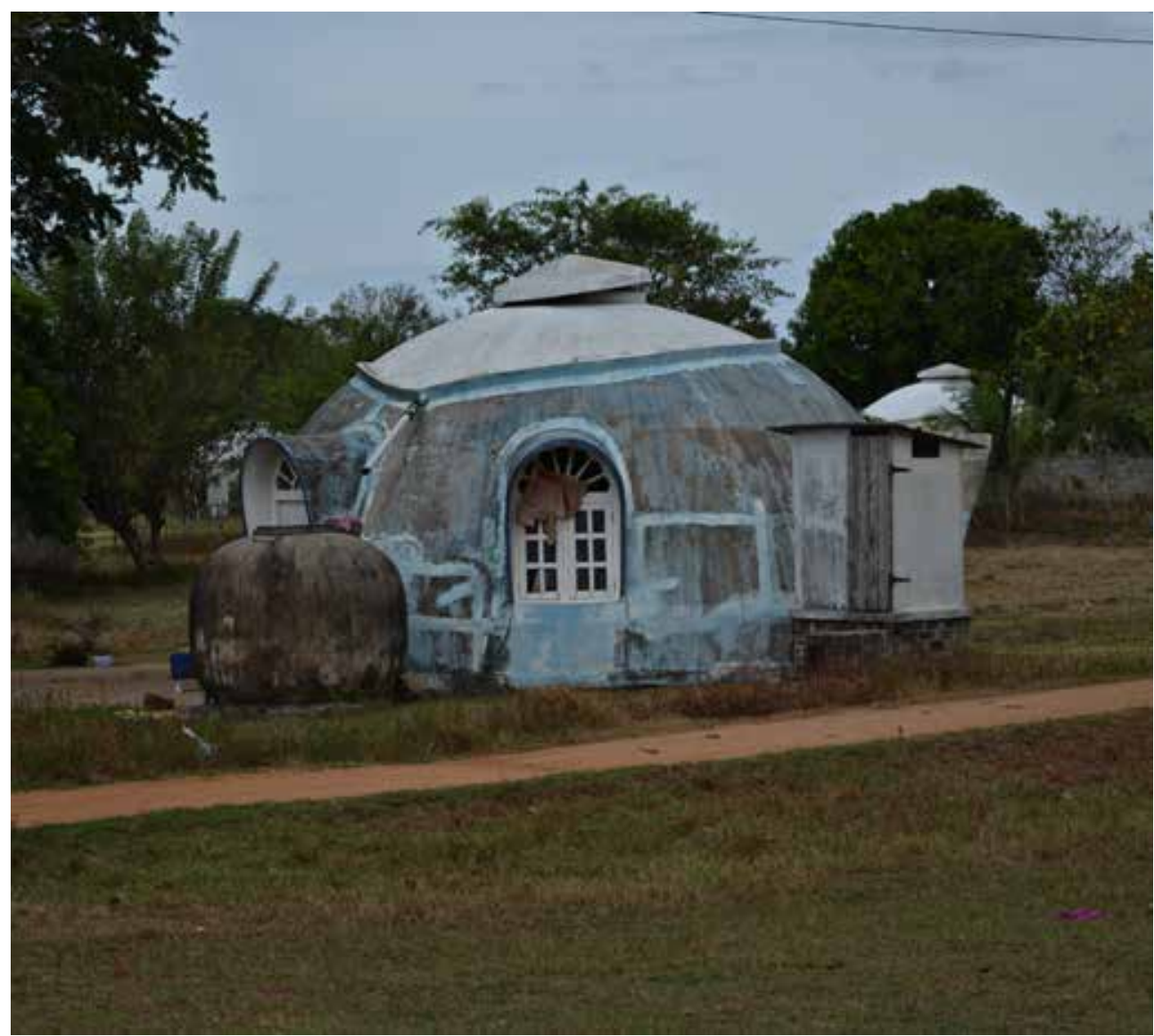

Figure 7. Abandoned home in Inspector Eatham with one of many abandoned detached external toilets.

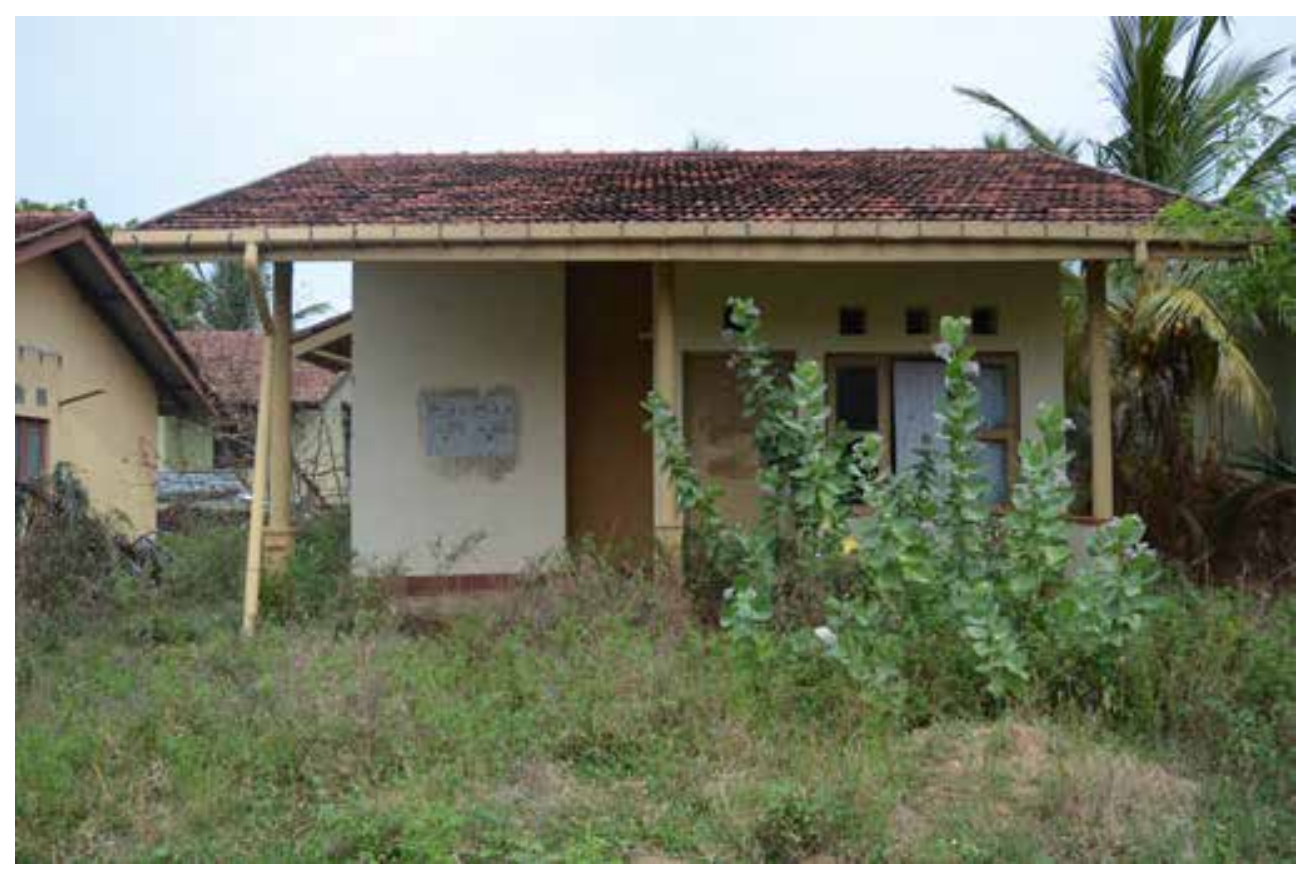

Figure 8. Abandoned home in the Japan International Cooperation Agency (JICA) development. 
difficult than in other areas of the island, leading to increasing costs for materials as demand increased with consistently limited supply. Demanding technical oversight or capital influx for maintenance and repairs by international donors or NGOs, these housing typologies indulge in the rhetoric of participatory and inclusive community projects while making complete handover to the community untenable. Ultimately, physically well-constructed housing that does not anticipate cultural, economic, and environmental needs can become obsolete artificially quickly, long before weathering or future natural disasters might pose problems.

\section{Foreign Dependence and Construction Issues in Prototypical Units}

Static prototypes that prioritize a commodity object-form of the house, even durable and disaster-proof models, tend to be especially dependent on international oversight, design, construction, repair, and maintenance. After the tsunami, NGOs including JICA and SHF selected such prototypical dwellings before securing details of site or infrastructure..$^{53}$

SHF suggested that its reinforced concrete prototype, which uses inflatable formwork imported from the Netherlands that requires the constant use of strong air pumps to maintain its domed shape during construction, could be adopted by locals without direct oversight. However, building practice that depends on internationally imported materials and high-energy input to operate pumps is poorly suited to the infrastructural realities of the East Coast, particularly given the difficulty of securing high quality concrete construction. Other researchers have noted that unsupervised concrete building in Sri Lanka is often significantly hindered by construction quality issues, including inappropriate material ratios, insufficient steel reinforcement, and poor curing. ${ }^{54}$

Generic prototypes fail to address directly such problems in local cultures of construction or the practical and financial appropriateness of global standards like reinforced concrete construction in low-income rural areas in tropical climates, where cement and steel reinforcement are expensive imported commodities. ${ }^{55}$ These projects create a paradigm of unequal partnership, in which international organizations contributing labor and expertise have unrestricted agency and are geographically mobile, while locals - who must adopt foreign dwellings - are tethered in place due to global inequity, unable to source materials cheaply for management or repair, and potentially lacking the knowledge and skills to effectively repair the structure. For this scheme to be longitudinally sustainable, the transfer of knowledge regarding the use of pumps, best practices for repairs, proper concrete and scaffolding construction techniques are critical, and must be given as much importance as the material transfer of the physical homes.

Barriers to Physical Adaptation: Macro- and Micro-Scale

It is critical that occupants are able to alter their dwellings to adapt to their changing needs. In post-disaster situations, it is paramount that 
housing constructed immediately in the aftermath of a natural disaster can be altered and reconfigured to the requirements of families after they have recovered and re-established their livelihoods. We suggest specific reasons why inhabitants do not easily physically adapt to the models we investigated: site planning and architectural characteristics. The site strategy of the JICA project (see Figs. 5,8 ) creates small, fenced lots of approximately $230 \mathrm{~m}^{2}$ [2,476 sq. ft.]. While the house model built from a UN prototype uses standardized construction methods familiar to local builders, the small lots and serial arrangement are reminiscent of conservative western single-family residential developments, on which it would be difficult to significantly extend or modify a home, and impossible to construct a second home for non-nuclear family. ${ }^{56}$

Local authorities who would normally approve sites, infrastructure and accompanying public services were largely backlogged and bypassed in the aftermath of the tsunami, leading to poorly planned, paved streets for vehicular access that restrict possibilities to convert and repurpose outdoor spaces. While SHF's domes fit more readily into larger existing plots, with ample space for extension, their unfamiliar geometry may have proved a barrier to meaningful modification (see Fig. 7). The beneficiaries themselves were critical of the one-size-fits-all approach that ignored household size, age and disabilities, therefore requiring owner-built modifications and extensions after donor funding had been spent by international organizations, not the inhabitants themselves. ${ }^{57}$ Without channels for input during the design process, any modifications or alterations that happen after construction are completed when families have the economic means to alter their homes. Yet the economy of the East Coast is isolated from the rest of the nation, making economic recovery challenging beyond the initial influx of aid in the direct aftermath of the tsunami.

\section{Climate Considerations and Site Ecology}

The coastal climate of Sri Lanka has wet and dry seasons regulated by the Indian Ocean monsoon and a generally hot-humid climate year-round. In the absence of costly air conditioning requiring electricity or gas, both of which are luxuries on the impoverished East coast, natural ventilation is necessary for thermal comfort. In the construction of housing, passive cooling techniques, particularly housing orientation toward the south, from where wind blows off the Indian Ocean during the dry season, offer an opportunity to capitalize on dependable natural phenomena for cooling. The totality of destruction after the tsunami allowed for the wholly new design and construction of housing appropriately oriented toward the south and also to avoid the hottest mid-afternoon sun. ${ }^{58}$ Drawing from the vast body of literature on design for regional climate, including Victor Olgyay's Bioclimatic Approach (1963), Baruch Givoni's Man, Climate and Architecture (1969), and Otto H. Koenigsberger et al.'s Manual of Tropical Housing and Building (1975), devices for passive cooling at smaller scales, 
including extended eaves and cavity walls, should be easily accessible and incorporated into all tropical housing schemes, yet these basic concepts were not used in the constructed aid housing. ${ }^{59}$ The majority of the JICAsponsored homes are oriented along an east-west axis, and by their nature the SHF domes are non-directional. Neither have significant eaves or use cavity walls. In the investigated projects, the substantial thermal mass of reinforced concrete construction is used inappropriately - for example, as exterior shell - given the mild nighttime temperatures and hot afternoons of Sri Lanka's tropical climate.

Furthermore, many landscape features that were commonplace before the tsunami were not effectively reintroduced into the site strategies developed for either of the developments. Viable cropland, particularly near and integrated with small-plot residential areas, is imperative for the survival of Sri Lanka's poorest citizens, who often rely on sustenance gardens for nourishment. ${ }^{60}$ Yet the available land in Inspector Eatham is sparsely vegetated and mostly dry, and plots in the project to the north are too small for residential gardens. ${ }^{61}$ We saw only one substantial vegetable growing garden around the remaining occupied home, and three fishermen interviewed noted the poor soil which has been stripped without groundcover. Both community members and experts noted the increased salinity of the soil after the tsunami penetrated inland, which significantly hindered the rice crop, but which is believed to have had lasting effects on the soil quality. A water supply for residential gardens could not be secured in Inspector Eatham because local rice farmers had preexisting claims, and local authorities and public service departments were not able to mediate the procurement of water. ${ }^{62}$ Soil building for individual fruit and vegetable plots, vegetative cover to improve air quality by grounding dust and sand particles, and large tree planting to increase shade cover were neglected by aid agencies in the interest of completing physical infrastructure such as asphalt roads. Shaded areas provided by vegetation become particularly critical in housing plots that do not include common indoor spaces and shared buildings that have traditionally been integral parts of Sri Lankan communities. ${ }^{63}$ Interviewed community members complained about the lack of appropriate space for public outdoor activities, particularly religious activities. The SHF community has a community space that is built using the same methods as residential houses but is considerably larger, and is one of the few projects within the site that was not observed to be littered. The authors noted that this might be exacerbated by roadways and access points that were not preplanned, but placed at the conclusion of building projects wherever space could be found, and have begun to erode during times of heavy rainfall.

\section{Cultural Considerations}

Questions of cultural and livelihood appropriateness were mostly specifically articulated in reference to kitchen design. Throughout the 
tsunami-affected area, many homes reconstructed by foreign donors were equipped with ventilation appropriate for gas-burning stoves, not the traditional biomass-burning models. This design was undertaken in consideration of the deforestation of the East coast and depletion of biomass sources, as well as the negative health impacts of burning biomass for cooking. However, gas is unaffordable for the majority of families along the East coast, $75 \%$ of whom live beneath the poverty line. ${ }^{64}$ Recipients of these homes added ventilated attachments to their home built of cadjan mats, or continue to cook using biomass stoves in improperly ventilated areas. In addition, in homes constructed with only two rooms and without a chimney, there is no adequate place to designate as a kitchen (Fig. 9).

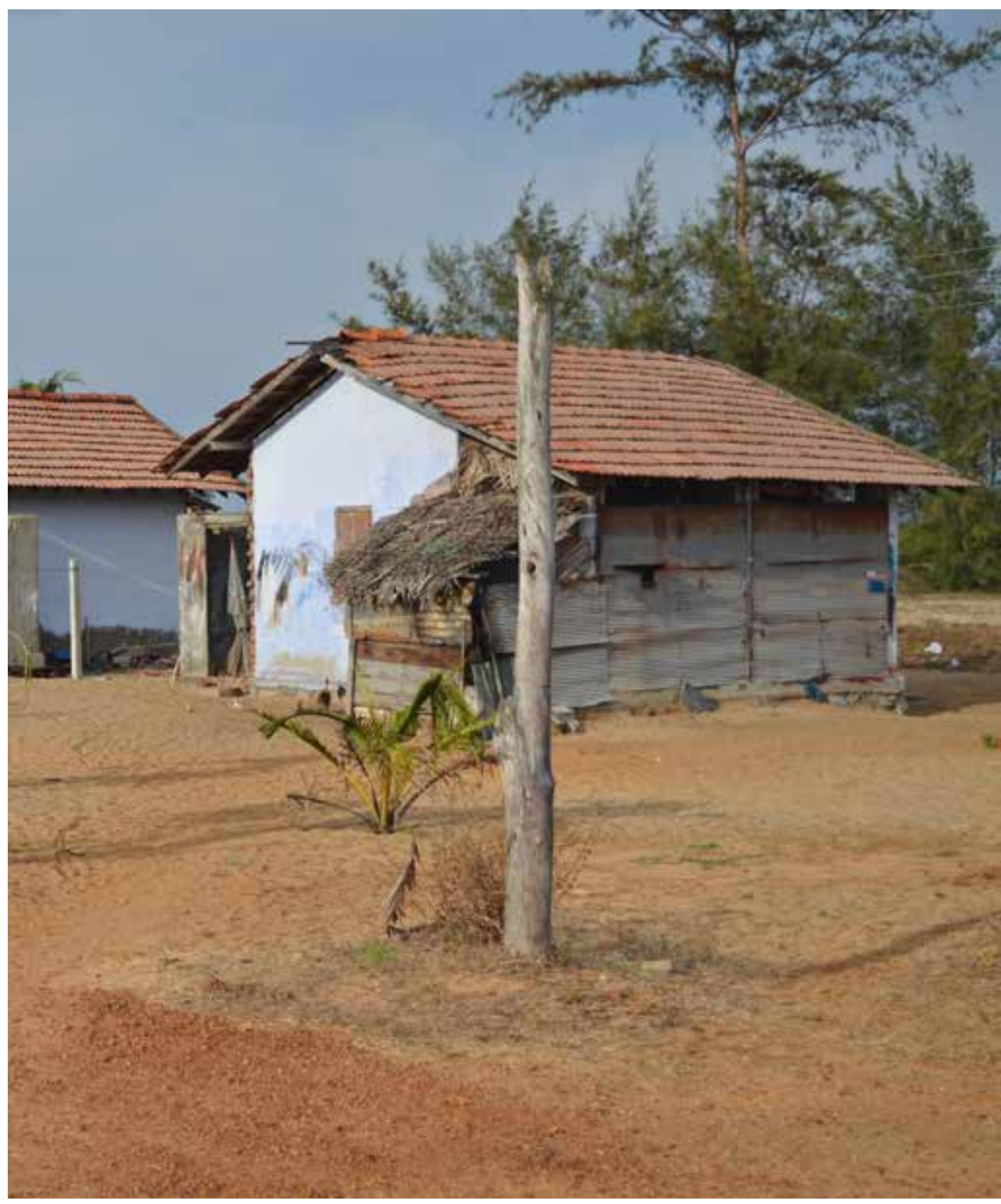

Figure 9. Relief aid housing unit with informal kitchen enclosure, used for biomass cooking. 
The close proximity of the kitchen to bathroom in the JICA development is considered unhygienic culturally, thus requiring the reconfiguration of the home after the NGO had completed construction using the resources of the family. We saw few modifications to the homes in the JICA development, as the concrete structure did not allow for the extension of the home except for the addition of cadjan rooms on the exterior of the home, inaccessible through the interior of the house, and none except for crude repairs of glass windows at the SHF site using discarded cardboard. Throughout the SHF site, the toilet complexes, located separately from the home, were in a state of disrepair, with inhabitants abandoning the elevated toilets.

The abandonment and vacancies we observed in the two projects were often attributed by community members to a limited understanding by foreign NGOs for Sri Lankan cultural history and programmatic distribution. The abandonments were not on the periphery of the JICA or SHF sites, but within the interior system of streets created for the projects, suggesting that the gridded urban layout placed families within close proximity of one another without taking into consideration pre-existing community dynamics.

Religious and ethnic tensions that arise when Tamils and Sinhalese have distributed homes within the same developments cannot be diffused with inventive housing models alone. Tamils have a strong oral architectural history that also existed in southern India known as "Vaastu shastra," which imposes stipulations on land use and planning, particularly regarding the alignment and direction of principal rooms. Donor-driven models that provide a single housing layout may not appropriately address these requirements, resulting in a home that may not be occupied due to auspicious religious or ethnic concerns. ${ }^{65}$ Both Tamil and Sinhalese fishermen expressed concern that bribes paid to government officials allowed some families to own many homes while other families were left without shelter. Shifting ethnic dynamics since the tsunami are revealed in the census conducted by the Government of Sri Lanka, with a decrease in the population identifying as ethnic Tamil from $40.39 \%$ in 2007 to $39.79 \%$ in 2012, and an increase in the Sinhalese population from $21.64 \%$ to $23.15 \%$ during the same period. This trend is part of a larger trajectory that has seen the number of ethnic Tamils in the eastern region reduced from $59 \%$ in the late 1800 s, while the Sinhalese population has dramatically increased from just $4 \%$ of the eastern population. ${ }^{66,67}$

Whether shaded by extended eaves or vegetation, the outdoor frontal space in Sri Lankan homes generally serves as an extension for work during the day and socializing during the evening, as well as subsistence food production. ${ }^{68}$ Fishermen interviewed stressed the importance of being able to complete tasks like weaving nets and repairing lines in or near the home for fear of theft if items are left on the beach. In both SHF and JICA's housing projects, this space was architecturally unacknowledged 
and largely unshaded, making prolonged outdoor work or socializing near the home impossible in the tropical climate. Extended families commonly live under one roof, making the small single-family houses, conventional or domed, unsuitable for many families granted homes. ${ }^{69}$ The proximity of family members was not consulted in the allocation of these homes, and one standard house was granted even in cases where extended families were previously cohabiting, problems which could have been ameliorated by more diversity in the size and plan of relief homes. Such ignorance to familial cultural considerations, in addition to the unfamiliar construction materials and small lots, may have made the abandonment or vacancy of houses preferable to modification for families to whom such houses were allocated. Housing as a deliverable cannot address the structural issues native to societies without directly engaging the social fabric of communities, requiring local consultants and longitudinal monitoring and mediation of completed projects.

Stranded Illiquid Assets

Stranded assets lose economic value well ahead of their anticipated useful life due to changes in market forces, societal norms, or environmental shocks. ${ }^{70}$ Aid housing projects risk becoming this kind of liability when useful social, environmental, and economic context is ignored in favor of universal prototypes. In the case of Sri Lanka's eastern coast, residents elected to vacate their allocated homes in settlements superficially modeled on international urban or architectural schemes. Locals identified many plots and homes within both the SHF and JICA developments that stood abandoned, and noted that many families owned multiple vacant properties but inhabited only one. Although expensive, structurally robust aid housing built with foreign design and construction techniques satisfies an immediate demand for safety and security, housing in the form of prescriptive giftsin-kind undermines the ability of local families to respond, adapt, or migrate when facing contingencies in their environment and economy, such as flooding that may inundate or salinate nearby farmland, or urban reconfiguration that may result from shifting shoreline topography.

\section{RESILIENCE}

\section{Recommendations}

The occupants of peripheral rural areas and humanitarian benefactors must make many difficult choices in the face of increasing environmental volatility. In the future, there will likely be less aid assistance available to those living on the coast outside major metropolitan areas, particularly in impoverished nations. This necessitates a difficult shift in the nature of aid from the typological towards the systemic - from the long-term expensive prototype to a low-cost, high-turnover, resilient culture of building. 


\section{Vernacular Materials}

Vernacular building materials, particularly those that require minimal labor such as cadjan mats, offer adaptable, climatically appropriate solutions to issues of sustainable housing. The disruption of vernacular knowledge in Sri Lanka has resulted in a proclivity toward inappropriate western building materials and standards that disregard the realities of the tropical climate, Indian Ocean monsoon, and ignore needs for low-cost sustainably sourced housing. The integration of vernacular building materials such as cadjan with technical specifications that relate to disaster risk prevention - including rock and cement foundations that elevate living spaces beyond sand or dirt floors, mosquito nets, and weighted roofs - provides sustainable solutions that can be adequately transferred to communities after international organizations have departed. The suggestion that traditional building materials are primitive or unsafe, and therefore should be disregarded, must be reconsidered in the context of each housing project. ${ }^{71}$ Their rapid turnover, easy adaptation, and low cost would require frequent and robust local engagement in architecture, planning, and construction practice, and could help provide a ready framework for absorption of ecological and economic shocks. The east coast saw dramatic inflation in the cost of materials in the aftermath of the tsunami due to vastly increased demand for imported materials via underdeveloped supply chains.

\section{Technical Training}

Solutions are found at the nexus of the spatial and social. Frameworks that provide technical specifications in a common language are useful only when paired with technical training that allows builders and carpenters to mobilize locally, offering agency to communities upended by natural disaster. Critically, during the reconstruction process the National Housing Development Authority provided a manual based on their previous successful projects in coastal Sri Lanka, Guidelines for Housing Development in Sri Lanka (2005), which was largely ignored by both the Government of Sri Lanka and foreign organizations. The best practices guide provides a framework for community engagement, technical specifications, and climatically appropriate design. ${ }^{72}$ To bridge the gap between local, tested expertise and foreign skills and knowledge bases, "train the trainer" seminars offered continuously to at-risk communities, sponsored and overseen by foreign NGOs but taught by local designers and organizations might promote experimentation with traditional and imported forms, and increase both physical and social resilience.

A part of owner-driven housing schemes elaborated on by the United Nations Habitat Program, training seminars that teach community members building and technical skills work by harnessing the capabilities of the community before a disaster, creating a network of community members capable of proactively sharing their skill set. The Indian Housing Program 
sponsored by UN Habitat in the northern districts of the island capitalized on this knowledge transfer, and offered specialized training from architects and designers to homeowners, including troubleshooting during the construction process. ${ }^{73}$ On the ground training can work in concert with technical documentation provided by international donors and NGOs, allowing for housing prototypes to be offered while homeowners possess the information to modify them to be culturally and familiarly appropriate. This kind of training can appropriate foreign knowledge and integrate it within a community, as a longer timescale for knowledge transfer ensures that trainers can modify knowledge into best practices that integrate with existing ones.

\section{Local Landscapes}

The resilience of the landscape must be considered immediately following a natural disaster. The landscape built environment and its surrounding landscape must not be treated as isolated or opposing phenomena. The construction and re-building of physical infrastructure must not be divorced from their ravaged environs. Failing to provide for longitudinal recovery beyond physical shelter, including the establishment of sustainable food systems, shade and bioremediation using reeds and other plants, compound the inability of geographically isolated communities to recover after disaster. Rural communities may be re-removed from global supply chains after foreign intervention in the immediate aftermath of a natural disaster, resulting in a lack of materials to sustain new constructions or public works systems that use materials found outside of the area. Dwellings along the beach can be further protected by the establishment of greenbelts that reduce flooding and the distance that waves travel inland; planting a dense vegetative understory between dwellings and the ocean offers defense against inundation, and can be sowed in concert with coconut palms or other income-generating species that establish new sources of economic livelihoods for families. ${ }^{74}$ Small-scale earthworks, including mounds and berms that can be used to catch water, accumulate topsoil to plant larger trees that produce shady microclimates, and offer immediate protection from flooding when built around dwellings, should be considered integral to the recovery process, and included in community plans.

\section{Building Agency}

A return to primitivism is neither required nor suggested. Instead, support for localized knowledge that builds agency and the transfer of knowledge and hard skills, not rigid typologies, offer remote societies the opportunity to propel forward even when they return to geographic isolation. Best practices that treat the community as an asset-base for development and that do not rely on a constant influx of foreign aid help to promote longevity and sustainability of projects, but treating the construction of 
dwellings as an objective with a clear end ignores the realities of social life and civil and municipality works that are critical for a functioning, robust, healthy society. Specifically included within this framework is proper construction of sewage treatment, roadways, and common places, which are often neglected by international NGOs or thought of as secondary. On Sri Lanka's eastern coast, mitigating ethnic tensions and the sources of decades of civil war is a critical priority, and should be seen as such, not as an afterthought to physical reconstruction in the wake of a natural disaster. Unresolved ethnic tensions and inequity are still legible across the country, particularly in legislation on the East Coast, and psychological barriers within communities segregate physical assets, such as the JICA housing compound. In light of the disproportionate poverty of the coast compared to predominantly Sinhalese areas, conflicts that arise from unequal distribution (or aid perceived as such) might be managed better by frameworks for distributed, bottom-up knowledge.

\section{Urgency}

Environmental and economic changes will begin to take place in low-lying Sri Lanka long before the end of the 50-year projected lifespan of SHF's dome houses. The frequency of intense rainfall events is likely to increase due to anthropogenic climate change, coupled with projected sea level rise across the globe of up to $1,31 \mathrm{~m}[4.30 \mathrm{ft}$.] by 2100 , a figure that has the potential to inundate 25.000 ha $[61,776$ acres] of Sri Lankan coastline, including the eastern seaboard..$^{75,76,77}$ Furthermore, the potential for natural disasters is greatly exacerbated in the context of climate change, increasing the likelihood of massive displacement and reconstruction projects that will be funded primarily through local channels, necessitating the creation of usable spatial frameworks that provide agency to Sri Lankan households before, during, and in the aftermath of natural disasters. ${ }^{78}$

\section{Limitations and Future Research}

Limitations of this study included the language barrier between English and Tamil, requiring a translator who expressed a clear bias for the Sinhalese population, and restricted access to Tamil inhabitants of the typologies investigations. Data from the Government of Sri Lanka was accessed online, and there are clear gaps in information accessible relevant to the East Coast, which were supplemented, when available, with information from the LTTE, which must be considered biased due to the history of Civil War within the country.

There is a clear need for continuing research on disaster relief housing in the context of global climate change and projected increases in resource scarcity and growing economic inequality. Future research that studies differences in vernacular architecture, between the Tamil and Sinhalese tradition could greatly contribute to best practices in culturally 
appropriate design, and more importantly create a set of best practices and construction standards to follow in the production of housing. Research into "Vaastu shasthra," a traditional Tamil set of beliefs regarding land use and planning, is very limited, and must be used to further best practices for housing that will not be abandoned due to ethnic or religious reasons. Further research that quantifies the number of abandoned houses provided by in-kind, donor-driven aid across tsunami-affected areas in Sri Lanka will be useful in determining the role of ethnic conflict in housing allocation, and suggest where design interventions can be most impactful.

\section{Notes}

1. John Telford and John Cosgrave, Joint Evaluation of the International Response to the Indian Ocean Tsunami: Synthesis Report (London: Tsunami Evaluation Coalition, 2006), 16. 2. Hideaki Nakazato and Osamu Murao, "Study on Regional Differences in Permanent Housing Reconstruction Process in Sri Lanka after the 2004 Indian Ocean Tsunami," Journal of Natural Science Disaster 29 (2007): 63.

3. Sisira Jayasuriya and Peter McCawley, The Asian Tsunami: Aid and Reconstruction after a Disaster (Northhampton, UK: Asian Development Bank, 2010), 127.

4. Michael Flint and Hugh Goyder, Funding the Tsunami Response (London: Tsunami

Evaluation Committee, 2006), 23.

5. David Stone, "Sri Lankan Civil War," in The Encyclopedia of War, ed. Gordon Martel (London: Wiley-Blackwell, 2012), 190-91.

6. Department of Census and Statistics, "Table A3: Population by District, Ethnic Group and Sex," Census of Population and Housing of Sri Lanka, 2012, accessed August 15, 2017, http://www.statistics.gov.Ik/PopHouSat/CPH2011/Pages/Activities/Reports/FinalReport/ Population/Table\%20A3.pdf.

7. Randall Kuhn, "Facts on the Seashore: Conflict, Population Displacement, and Coastal Displacement on the Eve of the Sri Lankan Tsunami," in Tsunami Recovery in Sri Lanka: Ethnic and Regional Dimensions, ed. Michele Gamburd and Dennis McGilvray (London: Routledge, 2009), 5.

8. LTTE Peace Secretariat, "Demographic Changes in the Tamil Homeland in the Island of Sri Lanka over the Last Century," 2008, accessed November 20, 2017, www.sangam. org/2008/05/Demographic_Changes.pdf.

9. Government of Sri Lanka, Post-Tsunami Recovery and Reconstruction. Joint Report of the Government of Sri Lanka and Its Development Partners (Colombo, Sri Lanka: Government of Sri Lanka, 2005).

10. Catherine Brun and Ragnhild Lund, "Making a Home during Crisis: Post-Tsunami Recovery in a Context of War, Sri Lanka," Singapore Journal of Tropical Geography 29 (2008): 277.

11. Jayasuriya and McCawley, The Asian Tsunami, 126.

12. Stone, "Sri Lankan Civil War."

13. Jayasuriya and McCawley, The Asian Tsunami, 133.

14. Ibid., 134.

15. Jennifer Hyndman, "The Securitization of Fear in Post-Tsunami Sri Lanka," Annals of the Association of American Geographers 97 (2007): 364.

16. Institute for Policy Studies of Sri Lanka. Sri Lanka State of the Economy 2005 (Colombo, Sri Lanka: Institute for Policy Studies, October 2005).

17. Action Aid International, Tsunami Response: A Human Response (Colombo, Sri Lanka: Action Aid International, 2006), 9.

18. Ibid., 17.

19. Claude de Ville de Goyet and Lezlie Moriniere, The Role of Needs Assessment in the Tsunami Response (London: Tsunami Evaluation Committee, 2006), 112.

20. Brian Walker et al., "Resilience, Adaptability and Transformability in Social-ecological Systems," Ecology and Society 9 (2004): 8.

21. Ibid., 9. 
22. Sultan Barakat, "Housing Reconstruction after Conflict and Disaster," Humanitarian Practice Network Report 43 (London: Overseas Development Initiative, 2003), 31.

23. Brun and Lund, "Making a Home," 278.

24. Sultan Barakat and Steven Zyck, "Housing Reconstruction as Socio-Economic Recovery and State Building: Evidence from Southern Lebanon," Housing Studies 26 (2011): 135. 25. Robert Dale, "Divided We Stand: Cities, Social Unity and Post-War Reconstruction in Soviet Russia, 1945-1953," Contemporary European History 24 (2015): 496.

26. Barakat and Zyck, "Housing Reconstruction," 136.

27. William Walters, "Secure Borders, Safe Haven, Domopolitics," Citizenship Studies 8 (2004): 241.

28. Anthony Oliver-Smith, "Successes and Failures in Post-Disaster Resettlement,"

Disasters 15 (1991): 20.

29. Government of Sri Lanka, Post-Tsunami.

30. Gayani Karunasena and Raufdeen Rameezdeen, "Post-Disaster Housing

Reconstruction: Comparative Study of Donor vs. Owner-Driven Approaches," International Journal of Disaster Resilience in the Built Environment 1 (2010): 180.

31. United Nations Habitat Program, Asset-Based Approach to Community Development and Capacity Building, New York, 2008.

32. Susan G. Broadbent and D. Michael Broadbent, Rethinking Future UK Support to PostDisaster Reconstructions: Meeting Stakeholder Interests, Proceedings of the Conference on Post-Disaster Reconstruction: Meeting Stakeholder Interests (Florence, It.: 2006): 152.

33. Karunasena and Rameezdeen, "Post-Disaster Housing," 182.

34. Jayasuriya and McCawley, The Asian Tsunami, 132.

35. Hyndman, "Securitization of Fear," 363.

36. Jayasuriya and McCawley, The Asian Tsunami, 140.

37. Patrick Daly and Caroline Brassard, "Aid Accountability and Participatory Approaches

in Post-Disaster Housing Reconstruction," Journal of Social Science: Special Issue on Post Disaster Societies 39 (2011): 512.

38. Brun and Lund, "Making a Home," 277.

39. Michael Lyons, "Building Back Better: the Large-Scale Impact of Small-Scale Approaches to Reconstruction," World Development 37 (2009): 385.

40. John Twigg, "The Age of Accountability? Future Community Involvement in Disaster Reduction," The Australian Journal of Emergency Management 18 (2000): 56.

41. United Nations Office for the Coordination of Humanitarian Affairs, Guiding Principles on Internal Displacement (New York: United Nations, 2004), 17.

42. Richard Haigh et al., "A Study of Housing Reconstruction and Social Cohesion among Conflict and Tsunami Affected Communities in Sri Lanka," Disaster Prevention and Management: An International Journal 25 (2016): 577.

43. Action Aid International, Tsunami Response, 20.

44. E. Silva et al., Lagoons of Sri Lanka: from the Origins to Present (Colombo, Sri Lanka: International Water Management Institute, 2013), 5.

45. Ibid., 30.

46. Dina Umali-Deininger and Terrence Abeysekera, Promoting Agricultural and Rural Non-Farm Sector Growth in Sri Lanka (Washington DC: World Bank, 2003), xi.

47. Carli Hammer, "Optimization of Dome Housing in Sri Lanka" (MA thesis, Delft University of Technology, 2006).

48. I.A. Hameed, Construction Guide 01: Indian Housing Project, http://unhabitat.lk/wpcontent/uploads/2015/01/constguide.pdf.

49. United Nations Habitat Program, Good Practices and Lessons Learned in Post-Conflict Reconstruction in Sri Lanka (Nairobi: UN Habitat, 2017), 21.

50. Albert Korsok, "Dwelling Characteristics and Distribution in Ceylon," The Journal of Geography 70 (1971): 23.

51. Telford and Cosgrave, Joint Evaluation, 93.

52. Bambi Chapin, Childhood in a Sri Lankan Village (New Brunswick: Rutgers University Press, 2014), 115.

53. Iftekhar Ahmed and Darryn McEvoy, "Post-Disaster Housing Reconstruction: PostOccupancy Case Studies from Sri Lanka" (paper presented at the 44th annual conference of the Architectural Science Association, ANZAScA, Auckland, New Zeal., November 24-26, 2010). 
54. Judith Shaw and Iftekhar Ahmed, "Case Studies from India and Sri Lanka," Design and Delivery of Post-disaster Housing Resettlement Programs 6 (Melbourne: Monash Asia Institute, 2010), 30.

55. R.A.D.B. Samaranayake, "Pre- and Post-Tsunami Coastal Planning and Land-Use Policies and Issues in Sri Lanka," (paper presented the Workshop on Coastal Area Planning and Management in Asian Tsunami-affected Countries put on by the Food and Agriculture Organization of the United Nations, Bangkok, September 27-29, 2006).

56. Hameed, Construction Guide 01

57. Ahmed and McEvoy, "Post-Disaster Housing."

58. Shaw and Ahmed, "Case Studies," 27.

59. Ahmed and McEvoy, "Post-Disaster Housing."

60. R.A.D.B. Samaranayake, "Pre- and Post-Tsunami."

61. Hammer, "Optimization."

62. Rick Noordink, "A New Plan Making Model: the Development of a Plan Making Model Which Can Be Used as a Guiding Principle for Future Projects of Solid House Foundation" (BSc Thesis, University of Twente, 2008).

63. Ronald Lewcock, Barbara Sansoni and Laki Senanayake, The Architecture of an Island: The Living Legacy of Sri Lanka (Colombo, Sri Lanka: Barefoot PVT Ltd., 1998), xxi.

64. Shaw and Ahmed, "Case Studies," 24.

65. United Nations Habitat Program, "Good Practices," 15.

66. Department of Census and Statistics, "Population by District."

67. LTTE Peace Secretariat. "Demographic Changes."

68. Shaw and Ahmed, "Case Studies," 21.

69. Ibid., 41.

70. Generation Foundation, Stranded Carbon Assets: Why and How Carbon Risks Should Be Incorporated in Investment Analysis (New York: Generation Foundation, 2013), accessed August 13, 2017, https://www.genfound.org/media/1374/pdf-generation-foundation-strandedcarbon-assets-v1.pdf.

71. Shenuka de Sylva and Arnaud Leurquin, "Resilient Living Environments: Identifying a Design Approach to Creating Housing Suited to Culture and Context" (paper presented at the Asian Conference on the Social Sciences, Kobe, Japan, June 8-11, 2017).

72. National Housing Development Authority, Guidelines for Housing Development in Sri Lanka (Colombo, Sri Lanka: National Housing Development Authority, 2005), 32.

73. United Nations Habitat Program, Indian Housing Project: Rebuilding Homes,

Transforming Lives (Nairobi: UN Habitat, 2015).

74. Marcus Kaplan, Fabrice Renaud, and Guido Luchters, "Vulnerability Assessment and Protective Effects of Coastal Vegetation during the 2004 Tsunami in Sri Lanka," Natural Hazards and Earth Science Systems 9 (2009): 1491.

75. Richard P. Allan, "Human Influence on Rainfall," Nature 470 (2011): 345.

76. Robert Kopp et al., "Temperature-Driven Global Sea-Level Variability in the Common Era," Proceedings of the National Academy of Sciences in North America 113 (2016): E1439.

77. Disaster Management Centre, Hazard Profiles of Sri Lanka (Colombo, Sri Lanka: Disaster Management Centre, 2012), 137.

78. Milen Dyoulgerov, Vulnerability, Risk Reduction, and Adaptation to Climate Change:

Sri Lanka (Washington DC: The World Bank Group, 2011), 15.

\section{References}

Action Aid International. Tsunami Response: A Human Response. Colombo, Sri Lanka: Action Aid International, 2006.

Ahmed, Iftekhar, and Darryn McEvoy. "Post-Disaster Housing Reconstruction: Post-Occupancy Case Studies from Sri Lanka." Paper presented at the 44th annual conference of the Architectural Science Association, ANZAScA, Auckland, New Zeal., November 24-26, 2010.

Allan, Richard P. "Human Influence on Rainfall." Nature 470 (2011): 344-345.

Barakat, Sultan. "Housing Reconstruction after Conflict and Disaster." Humanitarian Practice Network Report 43. London: Overseas Development Initiative, 2003. 
Barakat, Sultan, and Steven Zyck. "Housing Reconstruction as Socio-Economic Recovery and State Building: Evidence from Southern Lebanon." Housing Studies 26 (2011): $133-154$.

Boano, Camillo. "'Violent Spaces': Production and Reproduction of Security and Vulnerabilities." The Journal of Architecture 16 (2011): 37-55.

Broadbent, Susan G., and D. Michael Broadbent. Rethinking Future UK Support to PostDisaster Reconstructions: Meeting Stakeholder Interests. Proceedings of the Conference on Post-Disaster Reconstruction: Meeting Stakeholder Interests (Florence, It., May 2006), $151-54$.

Brun, Catherine, and Ragnhild Lund. "Making a Home during Crisis: Post-Tsunami Recovery in a Context of War, Sri Lanka." Singapore Journal of Tropical Geography 29 (2008): $274-87$.

Chapin, Bambi. Childhood in a Sri Lankan Village. New Brunswick NJ, USA: Rutgers University Press, 2014.

Dale, Robert. "Divided We Stand: Cities, Social Unity and Post-War Reconstruction in Soviet Russia, 1945-1953." Contemporary European History 24 (2015): 493-516.

Daly, Patrick, and Caroline Brassard. "Aid Accountability and Participatory Approaches in Post-Disaster Housing Reconstruction." Journal of Social Science: Special Issue on Post Disaster Societies 39 (2011): 508-533.

Department of Census and Statistics. "Table A3: Population by District, Ethnic Group and Sex." Census of Population and Housing of Sri Lanka, 2012, http://www.statistics.gov.lk/ PopHouSat/CPH2011/Pages/Activities/Reports/FinalReport/Population/Table\%20A3.pdf. de Sylva, Shenuka, and Arnaud Leurquin, "Resilient Living Environments: Identifying a Design Approach to Creating Housing Suited to Culture and Context." Paper presented at the Asian Conference on the Social Sciences, Kobe, Jap., June 8-11, 2017.

de Ville de Goyet, Claude, and Lezlie Moriniere. The Role of Needs Assessment in the Tsunami Response. London: Tsunami Evaluation Committee, 2006.

Disaster Management Centre. Hazard Profiles of Sri Lanka. Colombo, Sri Lanka: Disaster Management Centre, 2012.

Dyoulgerov, Milen. Vulnerability, Risk Reduction, and Adaptation to Climate Change: Sri Lanka. Washington DC: The World Bank Group, 2011.

Fernando, Udan, and Dorothea Hilhurst. "Everyday Practices in Humanitarian Aid: Tsunami Response in Sri Lanka." Development in Practice 16 (2006): 292-302.

Flint, Michael, and Hugh Goyder. Funding the Tsunami Response. London: Tsunami Evaluation Committee, 2006.

Generation Foundation. Stranded Carbon Assets: Why and how Carbon Risks should be Incorporated in Investment Analysis. New York: Generation Foundation, 2013. Accessed August 13, 2017. https://www.genfound.org/media/1374/pdf-generation-foundationstranded-carbon-assets-v1.pdf.

Government of Sri Lanka. Post-Tsunami Recovery and Reconstruction. Joint Report of the Government of Sri Lanka and Its Development Partners. Colombo, Sri Lanka: Government of Sri Lanka, 2005.

Haigh, Richard, Siri Hettige, Maheshika Sakalasuriya, G. Vickneswaran, and Lasantha Namal Weerasena. "A Study of Housing Reconstruction and Social Cohesion among Conflict and Tsunami Affected Communities in Sri Lanka." Disaster Prevention and Management: An International Journal 25 (2016): 566-80.

Hameed, I.A. Construction Guide 01: Indian Housing Project. http://unhabitat.lk/wp-content/ uploads/2015/01/constguide.pdf.

Hammer, Carli. "Optimization of Dome Housing in Sri Lanka." MA thesis, Delft University of Technology, 2006.

Hyndman, Jennifer. "The Securitization of Fear in Post-Tsunami Sri Lanka." Annals of the Association of American Geographers 97 (2007): 361-72.

Jayasuriya, Sisira, and Peter McCawley. The Asian Tsunami: Aid and Reconstruction after a Disaster. Northhampton, UK: Asian Development Bank, 2010.

Kaplan, Marcus, Fabrice Renaud, and Guido Luchters. "Vulnerability Assessment and Protective Effects of Coastal Vegetation during the 2004 Tsunami in Sri Lanka." Natural Hazards and Earth Science Systems 9 (2009): 1479-94.

Karunasena, Gayani, and Raufdeen Rameezdeen. "Post-Disaster Housing Reconstruction: Comparative Study of Donor Vs.Owner-Driven Approaches." International Journal of Disaster Resilience in the Built Environment 1 (2010): 173-91. 
Kopp, Robert, Andrew Kemp, Klaus Bittermann, Benjamin Horton, Jeffrey Donnelly, W. Gehrels, Carling Hay, Jerry Mitrovica, Eric Morrow, and Stefan Rahmstorf. "TemperatureDriven Global Sea-Level Variability in the Common Era." Proceedings of the National Academy of Sciences in North America 113 (2016): E1434-E11441.

Korsok, Albert. "Dwelling Characteristics and Distribution in Ceylon." The Journal of Geography 70 (1971): 19-26.

Kuhn, Randall. "Facts on the Seashore: Conflict, Population Displacement, and Coastal Displacement on the Eve of the Sri Lankan Tsunami." In Tsunami Recovery in Sri Lanka: Ethnic and Regional Dimensions, edited by Michele Gamburd and Dennis McGilvray. London: Routledge, 2009.

Lewcock, Ronald, Barbara Sansoni, and Laki Senanayake. The Architecture of an Island: the Living Legacy of Sri Lanka. Colombo, Sri Lanka: Barefoot PVT Ltd., 1998.

Lyons, Michael. "Building Back Better: The Large-Scale Impact of Small-Scale Approaches to Reconstruction." World Development 37 (2009): 385-398.

Nakazato, Hideaki, and Osamu Murao. "Study on Regional Differences in Permanent Housing Reconstruction Process in Sri Lanka after the 2004 Indian Ocean Tsunami." Journal of Natural Science Disaster 29 (2007): 63-71.

National Housing Development Authority. Guidelines for Housing Development in Sri Lanka. Colombo, Sri Lanka: National Housing Development Authority 2005.

Noordink, Rick. "A New Plan Making Model: the Development of a Plan Making Model Which Can Be Used as a Guiding Principle for Future Projects of Solid House Foundation." BSc Thesis, University of Twente, 2008.

Oliver-Smith, Anthony. "Successes and Failures in Post-Disaster Resettlement," Disasters 15 (1991): 12-23.

Samaranayake, R.A.D.B. "Pre- and Post-Tsunami Coastal Planning and Land-Use Policies and Issues in Sri Lanka." Paper presented at the Workshop on Coastal Area Planning and Management in Asian Tsunami-affected Countries put on by the Food and Agriculture Organization of the United Nations, Bangkok, September 27-29, 2006.

Shaw, Judith, and Iftekhar Ahmed. "Case Studies from India and Sri Lanka." Design and Delivery of Post-Disaster Housing Resettlement Programs 6. Melbourne: Monash Asia Institute, 2010.

Silva, E, Jinadasa Katupotha, Oscar Amarasinghe, Herath Manthrithilake, and R. Ariyaratna. Lagoons of Sri Lanka: from the Origins to Present. Colombo, Sri Lanka: International Water Management Institute, 2013.

Stone, David. "Sri Lankan Civil War." In The Encyclopedia of War, edited by Gordon Martel, 190-91. London: Wiley-Blackwell, 2012.

Telford, John, and John Cosgrave. Joint Evaluation of the International Response to the Indian Ocean Tsunami: Synthesis Report. London: Tsunami Evaluation Coalition, 2006.

Twigg, John. "The Age of Accountability? Future Community Involvement in Disaster Reduction." The Australian Journal of Emergency Management 18 (2000): 51-58.

Umali-Deininger, Dina, and Terrence Abeysekera. Promoting Agricultural and Rural Non-farm Sector Growth in Sri Lanka. Washington DC: World Bank, 2003.

United Nations Habitat Program. Asset-Based Approach to Community Development and Capacity Building. New York: New York, 2008.

- - Good Practices and Lessons Learned in Post-Conflict Reconstruction in Sri Lanka. Nairobi: UN Habitat, 2017.

- - Indian Housing Project: Rebuilding Homes, Transforming Lives. Nairobi: UN Habitat, 2015.

United Nations Office for the Coordination of Humanitarian Affairs. Guiding Principles on Internal Displacement. New York: United Nations, 2004.

Walker, Brian, Crawford S. Holling, Stephen Carpenter, and Ann Kinzig. "Resilience, Adaptability and Transformability in Social-ecological Systems." Ecology and Society 9 (2004): 5-13.

Walters, William. "Secure Borders, Safe Haven, Domopolitics." Citizenship Studies 8 (2004): 237-60. 


\section{Credits}

Figures 1, 6-9: images by the Author.

Figures 2-5: drawings by the Author.

Kira Bre Clingen is an MLA candidate at Harvard University Graduate School of Design. She holds a BSci in Ecology and Evolutionary Biology, and a BA in Environmental Policy Studies and Asian Studies from Rice University in Houston, Texas. She has worked with several international NGOs regarding climate change vulnerability, and her work has been published by the Swiss Center for Security Studies and SAGE International.

E-mail: kbclingen@gmail.com

Mark Robert Bavoso is a BArch candidate at Rice University in Houston, Texas, where he received the 2016 William Ward Watkin Traveling Fellowship. He holds a BA in Architecture from Rice and has previously worked for the Office for Metropolitan Architecture in Hong Kong and WW Architecture in Houston. E-mail: markbavoso@gmail.com 